\title{
Solid Modeling in Professional Training of Specialists for Machine-Building Enterprises
}

\author{
Viktor Telegin, Igor Telegin
}

\begin{abstract}
The article considers the structure of the discipline "Engineering Graphics" which is based on the modern solid modeling technologies in the environment of software products made by Autodesk, and on traditional methods of Descriptive geometry, Mechanical drawing and Design planning. The characteristic of modern PDM-technologies is given. Special attention is paid to the issues of traditional and modern design methods compatibility. The objectives of the course "Engineering Graphics" are outlined. Some examples of graphic work, training and control methods are given. The place of the discipline "Engineering Graphics" in the General structure of educational process of training of highly qualified specialists for machine-building enterprises is defined.
\end{abstract}

Index Terms: Solid Modeling, Professional Training, Machine Building

\section{MODERN DESIGN TECHNOLOGIES}

Nowadays, the design process of products for machine engineering sphere is based on creating their $3 \mathrm{D}$ models [1-4]. Such models are used to perform calculations [4], imitate the operation of the product [5] and analyze different ways for the product improvement [6-8]. Using 3Dmodels manufacturing techniques of product details (or other constituent parts) are developed. 3D-models are also used to perform assembly operations $[1,8]$.

In recent years the technologies based on the development process of a real product and of its information model (its constituent 3D-model) at the same time to manage the product lifecycle (PDM Product Design Management) [9] are becoming increasingly popular. The known analogue is BIM-technology in building industry (Building Information Model) [10].

\section{TRADITIONAL CONSTRUCTION TECHNOLOGIES AND THEIR PLACE IN THE MODERN DESIGN PROCESS}

At first sight it seems obvious that traditional designing, based on the methods of Descriptive geometry and Engineering graphics [11, 12], and on the methods of Theoretical mechanics, Material resistance, the Theory of mechanisms and machines, etc., has become thing of the past. But it is not so in reality [13]. Computer technologies dramatically improve productivity and design accuracy. They also allow the analysis and

Revised Manuscript Received on July 09, 2019.

Viktor Telegin, Igor Telegin, Associate Professor, Lipetsk State Technical University, Lipetsk, Russia.vv.telegin@yandex.ru selection of solutions that meet the specified criteria. However, the engineer is responsible for defining the criteria and setting design tasks. The quality of its solution is determined by the level of competence of the engineer being formed, including traditional methods of design.

New technologies, including PDM-technologies, do not always just come to replace the outdated ones. The educational process in higher education is limited by time. If we talk about the discipline "Engineering graphics", which is discussed in the article, organizing methods of teaching on the principle of "first we master what was before and then we will study 3D-modeling" [13] is not correct. It is wrong not because of the fact that studying the discipline will take a lot of time, but because of the falsity of the approach. In the authors opinion, obsolete methods should be replaced with new ones, and if it is possible to keep the same scope and the content of the theory. The objective is not just to keep it, but to process taking into account the tools of 3D-modeling, the requirements of the Federal State Educational Standard and professional standards used in machine-building enterprise which are specialized in program products, for example in the product by Autodesk (the USA), Solidwork Corporation (independent company division Dassault Systemes France), Ascon (Russia) and others. It is obvious that the content of the revised course "Engineering Graphics" will be different from the traditional one but while maintaining its basic theoretical foundations [3, 12].

\section{THE STRUCTURE OF ENGINEERING GRAPHICS COURSE}

A student who has mastered the course of Engineering graphics must:

- have theoretical knowledge to work with 3D-objects;

- know how to use it to create design documentation for mechanical engineering products;

- have practical skills of working with 2D-graphics and 3D-modeling in modern program products.

In such a structure, to form the course "Graphics engineering" is difficult and time-consuming. In Lipetsk State Technical University the Department of Engineering graphics has been working in this direction for many years. The first results of this work were obtained, tested and published in 2013-2014 years. 
The structure of the discipline "Engineering graphics", being studied currently by first-year students of technical specialties of the Institute of Mechanical engineering in Lipetsk State Technical University is the following:

- Semester 1. 1 hour of lecture and 2 hours of practical classes, consultations, independent work. Only 3-4 credits, depending on the direction of training.

- Semester 2. 1 hour of lecture and 2 hours of practical classes, consultations, independent work. Like in semester 1 , in semester 2 there are 3-4 credits, depending on the direction of training. It is planned to replace 1 hour of lectures with an additional hour of practical training.

The software is Autodesk AutoCAD and Inventor Professional. The choice of software products of Autodesk is explained by the following reasons:

- recognized leadership on the Russian market, along with the companies Ascon and Solidworks Corporation, its popularity and wide enough distribution;

- the similarity of its interfaces and principles of work with software of other companies;

- high level of capabilities in the field of not only 3D modeling and design documentation development in accordance with ESCD, but also in the performance of complex calculations (strength and fatigue calculations, etc.) using traditional methods (disciplines of materials resistance, theory of mechanisms and machines, machine parts) and finite element methods;

- extensive import and export opportunities (3D models created in Autodesk Inventor and in SolidWorks are exported with virtually no loss and vice versa);

- Autodesk provides the ability to install licensed free software not only in computer classes of educational institutions, but on home computers of students (and this is the most important).

Management of the educational process in practical and lecture classes are carried out with the help of the program LiteManager Free [14]. The following features of the program can improve the quality and efficiency of the educational process:

- the demonstration of educational material and methods of work with the software (AutoCAD, Inventor) from the teacher's computer on every student's computer;

- real-time tracking of activities in the classroom of each student;

- interference in the student's work with software (AutoCAD, Inventor), for example during the process of 2D, 3D modeling, or drawing.

The methodical materials which are necessary to perform graphic works in software products Autodesk AutoCAD and Inventor Professional are found in online cloud storage services and are available both at practical classes, and at independent work on home computers. The Internet provides the access to the necessary literature, primarily to the texts of state standards. The theoretical part of the course "Engineering graphics" includes the study of the basics of descriptive geometry (the first semester) and engineering drawing (the second semester).

Three individual graphic works on the theme of positional and metric problems for points, lines and planes, face surfaces, surfaces of rotation have been planned. Each of the works is performed in an AutoCAD environment with the application of both the methods of descriptive geometry and 3D-modeling. Besides, of the 36 hours of practical training provided for in the curriculum in the semester, the first 8-10 hours are allocated for the acquisition of practical skills of working in the model AutoCAD space. It is extremely important that after being trained in semester 1, a student could perceive the surrounding objects as a result of operations of merging, subtraction and intersection of their surfaces (bodies) and could know the methods of performing all these operations.

The second semester is entirely devoted to the theory and practice of creating design documentation in accordance with the standards of ESKD engineering products in Autodesk Inventor Professional. The following graphic works are provided: 3D-model and part drawing (pattern "Detail"); 3D-model and drawing of bolt connection (patterns "Assembly" and "Scheme"); reading an assembly drawing or building a 3D-model of an item according to its assembly drawing; the design of the shaft reducer. The first two graphic works involve testing the basics of the theory and practice of drawing development. The third and fourth graphic work involves checking the improvement of knowledge and practical skills. One of the most important results of the training should be the realization that when developing a 3D-model of the product, its drawing, the student makes this product at this stage using a computer or appropriate software.

Control of mastering of the studied material by students. It is assumed that all the graphic works performed by students, for the most part, are performed in practical classes. Using LiteManager Free program makes it possible to save and analyze the results of the student's work at each lesson, if necessary. The system of Internet testing [15] is widely used to check the assimilation of the theoretical material. During the semester about five times the students are offered to perform the test tasks on the studied topics in the system of Internet simulators as part of independent work on their home computers. The final exam or test includes testing, usually in the FEPO system. 


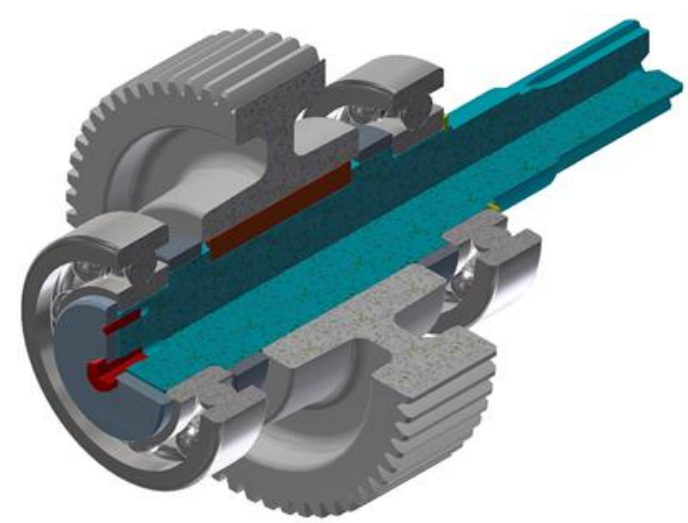

Fig. 1 shows a 3D-model of the shaft, created as part of the last graphic work is shown.

Fig.1. Shaft assembly - visual image. Design assignment.

Standard design details (bearings, key, washer, screw, pin, ring), the presence and location of the shaft elements (chamfers, fillets, grooves for the output of the grinding wheel, zinc holes), geometry parameters of standard shaft elements (slots), gear parameters (module, number of teeth, tooth angle, profile angle, displacement coefficient, face width and hub length are defined as the initial data for the design. The students establish any missing dimensions themselves.

As part of this work a student develops a 3D-model of the assembly (Fig. 1), its drawing (not given in the article) and the drawing of the shaft (Fig. 2).

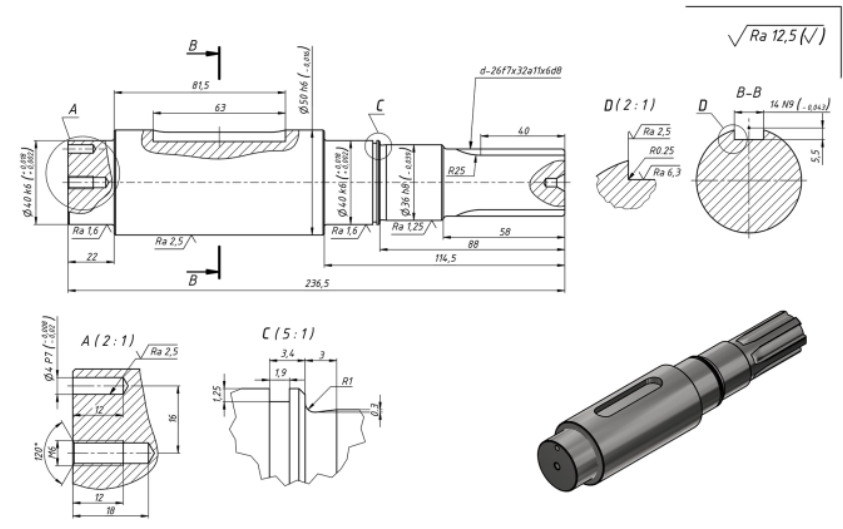

Fig.2. The drawing of the shaft.

\section{CONCLUSION}

When evaluating the final work (Fig. 2), we should keep in mind the fact that this is only the beginning of the design process training. Further, the students will study such disciplines as "Machine Parts", "Fundamentals of Interchangeability", and others. In the course of Engineering graphics such concepts as tolerances and landing, surface roughness are only mentioned.

Solid modeling methods are currently the basis of practical training of engineers in the fields of design, technology development and other areas of design. However, in the theoretical part of the training the role of the traditional design methods cannot be underestimated.

\section{REFERENCES}

1. S.A.Smyslov, N.V.Nosov, V.N.Mihelkevich, A.B.Puzankova, The competence-based approach to the design-technology preparation of bachelors for the enterprises of the machine-building cluster, News of the Samara Scientific Center of the Russian Academy of Sciences, v. 15(2-4), pp. 930-934 (2013)

2. V.V. Telegin, A.M. Kozlov, V.I. Sakalo, Solid Modeling and Dynamic Analysis of Mechanisms of Press-forging Machines, Procedia Engineering, v. 206, pp. 1258-1263 (2017)

3. V.V. Telegin, A.M. Kozlov, A.V. Kirichek, Solid Modeling in Autodesk Inventor at Initial Stage of Training of Specialists in Field Mechanical Engineering, ICIE 2018: Proceedings of the 4th International Conference on Industrial Engineering, pp. 1241-1247 (2018)

4. V. Telegin, A. Kozlov, T. Shumilova, Development and research of the rotating lever object as a dynamic model of a cycle mechanism, MATEC Web Conf. International Conference on Modern Trends in Manufacturing Technologies and Equipment (ICMTMTE 2018), v. 224, pp. 02078 (2018)

5. I.V. Revina, G.N. Boyarkin, Simulation of production process manufacturing parts, Omsk scientific bulletin, v. 6(162), pp. 230-234 (2018)

6. I.V. Telegin, V.V. Telegin, Mathematical model of the part shape and automation on its basis of the process of developing the drawing parameters of the axisymmetric forging, The Turkish Online Journal of Design, Art and Communication - TOJDAC ISSN: 2146-5193, v. 8(March 2018 Special Edition), pp. 458-464 (2018)

7. I. Telegin, T. Shumilova, Comparing the efficiency of flowsheets for hot die forging on crank presses, MATEC Web Conf. International Conference on Modern Trends in Manufacturing Technologies and Equipment (ICMTMTE 2018), v. 224, pp. 01092 (2018)

8. I.V. Telegin, I.M. Volodin, P.I. Zolotukhin, The mathematical modeling for assessing the effectiveness of hot forging extruded round in plan forgings on crank presses, International Journal of Engineering and Technology(UAE), v. 7(2), pp. 30-34 (2018)

9. Product Lifecycle Management (TAdviser - Russian Internet portal and analytical agency, 2010)

10. Improving the efficiency of design using BIM-technologies (Stins Coman, 2016)

11. V.I. Seregin, L.S. Senchenkova, N.G. Surkova, T.L. Beloborodova, Electronic geometric models in the structure of "Engineering Graphics" course, International scientific research journal, v. 8(62), pp. 88-93 (2017)

12. Yu.A. Korolev, S.Yu. Ustyuzhanin, Engineering Graphics: Textbook for universities. The standard of the third generation ( $\mathrm{SPb}$.: Peter, 2011)

13. L.G. Polubinskaya, A.P. Fedorenkov, T.R. Khusnetdinov, Computer graphics in the course "Engineering Graphics", VII International Scientific and Practical Internet Conference "Problems of the quality of graphic training of students in a technical college: traditions and innovations" (KGP-2017)

14. D.A. Yakhnovets, Litemanager (Certificate of State. reg. computer programs №2011618072 Russian Federation, 2011)

15. I.V. Demyanovich, Computer-based testing as a means of assessment of higher education students competences, Modern educational process: questions of theory and practice. Collection of works of the interregional scientific and methodological conference: in 2 volumes, pp. 47-51 (2018) 